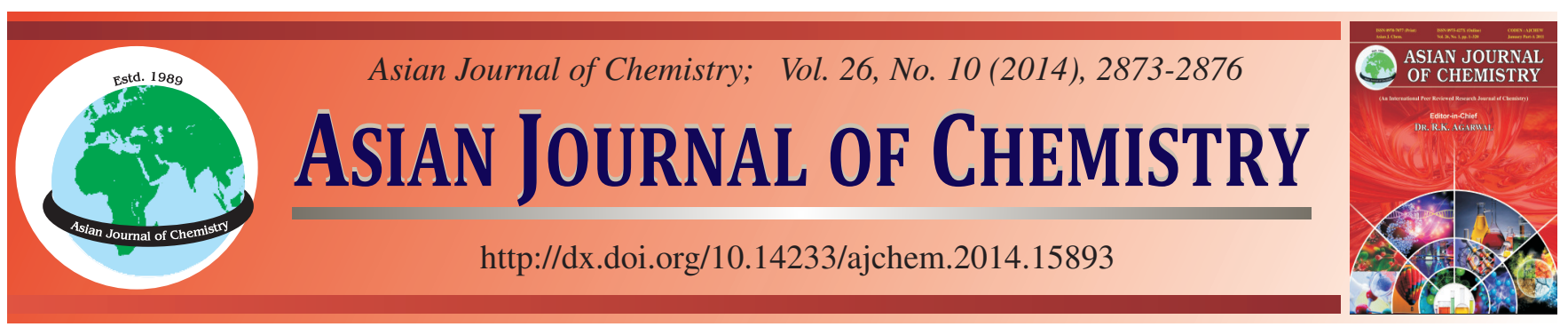

\title{
Efficient Synthesis of 5(4H)-Imidazolones and in vitro Antifungal Activity Studies Against Selected Phytopathogens
}

\begin{abstract}
Christopher Voosala , Lakshmi Narasimha Murthy Yellajyosula, Viplava Prasad Uppuleti and Padma Suhasini Kilaru
\end{abstract}
Department of Organic Chemistry \& FDW, Andhra University, Visakhapatnam-530 003, India

*Corresponding author: E-mail: chrissvoosala@yahoo.co.in

Received: 11 June 2013;

Accepted: 14 October 2013;

Published online: 10 May 2014;

AJC-15138

\begin{abstract}
A series of five new 1-(substituted phenyl)-2-phenyl-4-(substituted benzylidine)imidazole-5-one derivatives (or) 5(4H)-imidazolones have been synthesized adopting $\mathrm{SiO}_{2}, \mathrm{Al}_{2} \mathrm{O}_{3}-90$ and Y-faujasite (Y-H type) zeolite as catalysts. These compounds were assayed for their antifungal activity on three different selected phytopathogens which disparately affects the Jowar crop (Sorghum vulgare) of poaceae family. Among the screened target molecules, compound 18 exhibited potent inhibitory activity compared to the standard drug bavistine, which is worth for further investigation.
\end{abstract}

Keywords: Y-faujasite zeolite, Imidazolone, Phytopathogens, Antifungal activity.

\section{INTRODUCTION}

Imidazolones have been associated with several pharmacological activities ${ }^{1-4}$ such as antimicrobial (antifungal, antibacterial and antiviral), anticancer activity, CNS depressant activity etc. Benzylidene derivatives have been reported to possess anticonvulsant and MAO inhibitory activity. Shaw et al. ${ }^{5}$ have reported that certain 5-imidazolones act as cardiotonic agents. Thus construction of these heterocyclic systems using various synthetic methodologies is of great importance is combinatorial organic synthesis ${ }^{6}$ and medicinal chemistry.

Attempts have been reported to synthesize these compounds by several methods ${ }^{7,8}$ such as condensing glycine ester of acetimidic or phenylacetimidic acid in the presence of benzene, dioxane or acetone.

Though some of the imidazolones have been reported using microwave irradiation, a suitable support or sensitizer is invariable in many of these reactions ${ }^{9}$. Therefore a methodology in synthesizing these potent compounds is still a necessary requirement. To the best of our knowledge, the synthesis of imidazolones adopting zeolites ${ }^{10}$ (crystalline aluminosilicates of various metals) and its constituents i.e., $\mathrm{SiO}_{2}$ and $\mathrm{Al}_{2} \mathrm{O}_{3}$ as catalysts ${ }^{11,12}$ were not comparatively studied. Motivated by this fact, herein we report the yields of imidazolones adopting these catalysts and exposit their antifungal properties against specified pathogens viz., Fusarium oxysporum, Rhizoctonia solani and Curvularia lunata which destroyed the Jowar plants. The target molecules (17-21) were synthesized following the procedure described in Scheme-I.

\section{EXPERIMENTAL}

All the melting points were recorded on VEB Analytica Dreader, HMK hot plate and are uncorrected. IR spectra (KBr) were recorded on Perkin Elmer IR 841 spectrophotometer. ${ }^{1} \mathrm{H}$ NMR and ${ }^{13} \mathrm{C}$ NMR spectra were recorded on JEOL JNM FTNMR $(90 \mathrm{MHz})$ spectrometer using $\mathrm{CDCl}_{3}$ or DMSO $\left(d_{6}\right)$ and TMS as internal reference. GCMS were recorded on QP 5050A, Schimazu spectrometer. All the compounds showed satisfactory elemental analyses.

General procedure for the synthesis of oxazolones (7-11) by conventional and microwave assisted methods ${ }^{13}$ : A mixture of different substituted benzaldehydes (2-6) (2.3 $\mathrm{mmol})$, hippuric acid $(2.6 \mathrm{mmol})$, acetic anhydride $(7.2 \mathrm{mmol})$, sodium acetate $(2.4 \mathrm{mmol})$ were refluxed at $110^{\circ} \mathrm{C}$ with constant stirring for $4 \mathrm{~h}$. The crude product was separated, filtered and washed with ice cold ethanol, followed by boiling water and recrystallized from chloroform. All the five oxazolones (7-11) were characterized using advanced spectroscopic data.

In microwave assisted synthesis of oxazolones (7-11) $(450 \mathrm{~W}, 15 \mathrm{~min})$, all the reactants were taken in the same mole ratios as that were taken in the usual conventional method. It was made sure that acetic anhydride was not evaporated from the mixture. The product obtained by this method was identical with that of the conventional method.

General procedure for the synthesis of $5(4 \mathrm{H})$ imidazolones (17-21) using $\mathrm{SiO}_{2}, \mathrm{Al}_{2} \mathrm{O}_{3}-90$ and $\mathrm{Y}-\mathrm{H}$ zeolite ${ }^{14}$ : Oxazolones (7-11) $(0.01 \mathrm{~mol})$ were heated to reflux with substituted anilines (12-16) $(0.01 \mathrm{~mol})$ in a solution of slight 
<smiles>[R]c1ccc(C=O)cc1[R]</smiles>

1

\section{2-6}

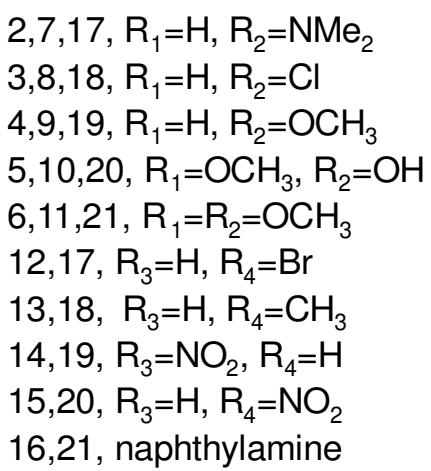

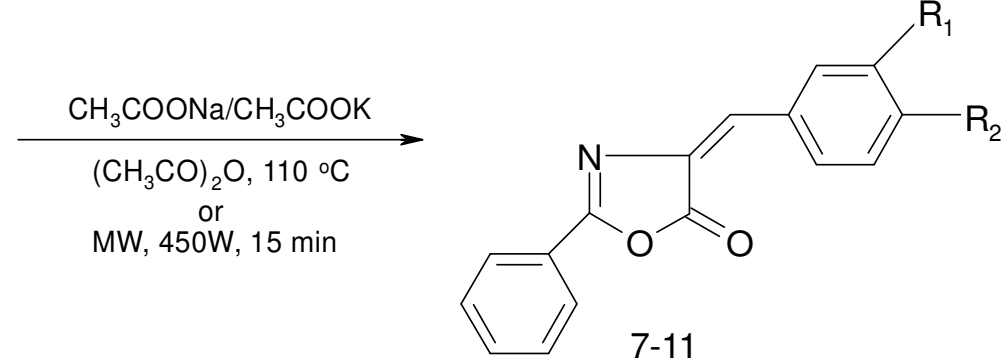<smiles>[R7]c1ccc(/C=C2/N=C(c3ccccc3)N(c3ccc([R])c([R])c3)C2=O)cc1[R6]</smiles>

$17-21$

Scheme-I

excess of pyridine $(0.01 \mathrm{~mol})$ in an oil bath at $150-170{ }^{\circ} \mathrm{C}$ with $\mathrm{SiO}_{2}, \mathrm{Al}_{2} \mathrm{O}_{3}-90$ or Y-H zeolite as catalyst $(2.5 \mathrm{~g})$. The excess of pyridine was distilled off in a Rotavapor, cooled and poured into crushed ice in $10 \% \mathrm{HCl}$. The crude imidazolone precipitated was filtered, dried over $\mathrm{MgSO}_{4}$ and chromatographed over Silica gel using hexane and ethyl acetate as eluants.

1-(4-Bromophenyl)-2-phenyl-4-(4'- $N, N$-dimethyl benzylidene)-imidazol-5-one (17): Light reddish solid, m.p. $152{ }^{\circ} \mathrm{C}$, IR (KBr, $\left.v_{\max }, \mathrm{cm}^{-1}\right): 2924,2854,2373,2339,1710$, $1649,1598,1525,1381,1162,761 ;{ }^{1} \mathrm{H}$ NMR $(90 \mathrm{MHz}$,

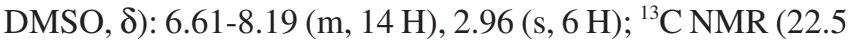
MHz, DMSO, $\delta$ ): 166.8, 164.6, 132.2, 128.3, 36.7; Mass: $\mathrm{m} / \mathrm{z}$ (446); Anal. calcd. for $\mathrm{C}_{24} \mathrm{H}_{20} \mathrm{~N}_{3} \mathrm{OBr}$ : C 64.57, H 4.48, N 9.41. Found: C 64.55, H 4.49, N 9.39.

1-(4-Methylphenyl)-2-anisyl-4-(4'-chloro benzylidene)imidazol-5-one (18): Pale yellow solid; m.p. $174{ }^{\circ} \mathrm{C}$; IR (KBr, $\left.v_{\max }, \mathrm{cm}^{-1}\right): 2960,2813,2319,2390,1700,1656,1620,1603$, 813; ${ }^{1} \mathrm{H}$ NMR (90 MHz, DMSO, $\delta$ ): 6.68-8.37 (m, $14 \mathrm{H}$ ), 2.4 (s, $3 \mathrm{H}) ;{ }^{13} \mathrm{C}$ NMR (22.5 MHz, DMSO, $\left.\delta\right): \delta$ 167.1, 164.8, 134.6, 131.5, 26.5; mass $m / z$ (372); Anal. calcd. for $\mathrm{C}_{23} \mathrm{H}_{17} \mathrm{~N}_{2} \mathrm{OCl}$ : C 74.09, H 4.56, N 7.51. Found: C 74.01, H 4.56, N 7.49.

1-(3-Nitrophenyl)-2-phenyl-4-(4'-methoxy benzylidene)imidazol-5-one (19): Lemon yellow solid; m.p. $121{ }^{\circ} \mathrm{C}$; IR $\left(\mathrm{KBr}, v_{\max }, \mathrm{cm}^{-1}\right): 3015,2930,2882,2320,1710,1635,1600$, 1580, 1215; ${ }^{1} \mathrm{H}$ NMR (90 MHz, DMSO, $\delta$ ): 7.03-8.35 (m, 14 $\mathrm{H}), 3.86$ (s, $3 \mathrm{H}) ;{ }^{13} \mathrm{C}$ NMR (22.5 MHz, DMSO, $\left.\delta\right): ~ 167.9$,
164.0, 132.1, 128.0, 54.2; mass: $\mathrm{m} / \mathrm{z}$ (399); Anal. calcd. for $\mathrm{C}_{23} \mathrm{H}_{17} \mathrm{~N}_{3} \mathrm{O}_{4}$ : C 69.17, $\mathrm{H} 4.26, \mathrm{~N} 10.52$. Found: $\mathrm{C} 69.15, \mathrm{H}$ 4.27, N 10.49 .

1-(4-Nitrophenyl)-2-phenyl-4-(3'-methoxy, 4'-hydroxy benzylidene)-imidazol-5-one (20): Yellow solid; m.p. $118^{\circ} \mathrm{C}$; IR $\left(\mathrm{KBr}, \mathrm{v}_{\max }, \mathrm{cm}^{-1}\right)$ : 3420, 3059, 2928, 1720, 1637, 1590, 1452, 1380, 1267, 1134, 813; ${ }^{1} \mathrm{H}$ NMR (90 MHz, DMSO, $\delta$ ): $9.3(\mathrm{~s}, 1 \mathrm{H}), 8.32(\mathrm{~d}, J=8.1 \mathrm{~Hz}, 2 \mathrm{H}), 7.01-7.92(\mathrm{~m}, 11 \mathrm{H}), 3.98$ (s, 3H); ${ }^{13} \mathrm{C}$ NMR (22.5 MHz, DMSO, $\left.\delta\right): \delta 168.9,163.8,131.6$, 127.2, 54.1; mass: $m / z$ (415); Anal. calcd. for $\mathrm{C}_{23} \mathrm{H}_{17} \mathrm{~N}_{3} \mathrm{O}_{5}$ : C 66.50, H 4.09, N 10.12. Found: C 66.48, H 4.10, N 10.12.

1-(Naphthyl)-2-phenyl-4-(4',5'-dimethoxy benzylidene)imidazol-5-one (21): Pale yellow solid; m.p. $211^{\circ} \mathrm{C}$; IR (KBr, $\left.V_{\max }, \mathrm{cm}^{-1}\right): 3017,2960,2814,2760,2318,1716,1660,1615$, 1490, 1316, 1211; ${ }^{1} \mathrm{H}$ NMR (90 MHz, DMSO, $\delta$ ): 6.82-8.20 (m, 16H), $3.85(\mathrm{~s}, 3 \mathrm{H}), 3.82(\mathrm{~s}, 3 \mathrm{H}) ;{ }^{13} \mathrm{C} \mathrm{NMR}(22.5 \mathrm{MHz}$, DMSO, $\delta$ ): 166.5, 160.9, 131.1, 126.5, 54.1, 54.3; mass: $\mathrm{m} / z$ (434); Anal. calcd. for $\mathrm{C}_{28} \mathrm{H}_{22} \mathrm{~N}_{2} \mathrm{O}_{3}$ : C 77.41, H 5.06, N 6.45. Found: C 77.39, H 5.06, N 6.43.

\section{RESULTS AND DISCUSSION}

The key intermediates i.e., 5(4H)-oxazolones (7-11) were synthesized ${ }^{13}$ in both conventional and microwave assisted methods in good yields. Subsequently the target compounds (17-21) were synthesized using $\mathrm{SiO}_{2}, \mathrm{Al}_{2} \mathrm{O}_{3}-90$ or Y-H zeolite ${ }^{14,15}$ as catalysts. 5(4H)-oxazolones (7-11) were heated to reflux with various substituted aromatic amines (12-16) consisting 
of various electron donating and withdrawing groups in a solution of slight excess of pyridine with these catalysts. Further work up and chromatography over silica gel using hexane and ethyl acetate resulted in the final products. Interestingly the reaction times were drastically less and high yields of the products were obtained adopting large pored Y-faujasite (Y-H zeolite $)^{16}$ as catalyst over $\mathrm{SiO}_{2}$ and $\mathrm{Al}_{2} \mathrm{O}_{3}-90$ as visualized from Table-1.

The structures of the target molecules were characterized by IR, NMR, mass and elemental analysis. A possible mechanism is shown in Scheme-II, refers to that, the large pore size of Y-faujasite type zeolite i.e., Y-H zeolite affected the dehydration effectively, thus paving way for increase in the yield of the products i.e., imidazolones (17-21) (Table-1) in less reaction times.

Evaluation of antifungal activity: Antifungal activity of the synthesized imidazolones (17-21) were tested against three fungal phytopathogens viz., Fusarium oxysporum, Rhizoctonia solani and Curvularia lunata which effect Jowar plant (local name: Zonnalu) (Sorghum vulgare) of the family Poaceae. The method adopted was cup-plate method. The compounds were tested at a concentration of 5, 25, 50 and $100 \mu \mathrm{g} / \mathrm{mL}$, each of $50 \mu \mathrm{L}$ against the above said fungal strains. Bavistine was taken as the standard drug for comparison of the results and DMSO as the control. Nutrient agar and Sabourds medium are used as culture media for these fungal phytopathogens.

In vitro antifungal activity of the target molecules (1721) was evaluated by cup-plate method ${ }^{17,18}$, starting with low concentrations viz., 5, 25, 50 and $100 \mu \mathrm{g} / \mathrm{mL}$ for their MIC (minimum inhibitory concentration) values. $50 \mu \mathrm{L}$ of each concentration was tested against the fungal phytopathogens i.e., F. oxysporum, R. solani and C. lunata. The MIC values and zones of inhibition were compared with Bavistine, a standard antifungal drug. Solvent employed was DMSO which showed no effect on the tested fungal strains. The results are presented in Table-2.

All the compounds (17-21) in general showed antifungal activity against the specified pathogens. Compound $\mathbf{1 8}$ showed a comparable activity to that of standard drug used (bavistine) against $R$. solani and compound 20 showed MIC value at 5 $\mu \mathrm{g} / \mathrm{mL}$ against $F$. oxysphorum which proved to be better than<smiles>C/C=C1/N=C(c2ccccc2)OC1([O-])[NH+]c1ccccc1</smiles><smiles>C/C=C1/NC(O)(c2ccccc2)N(c2ccccc2)C1=O</smiles><smiles>C/C=C1\N=C(c2ccccc2)N(c2ccccc2)C1=O</smiles><smiles>[CH][NH+](c1ccccc1)[C@@]1(O)OC(c2ccccc2)=N/C1=C/C</smiles>

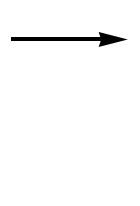<smiles>C/C=C1/NC2(c3ccccc3)C=C1NC(=O)C(c1ccccc1)CC2</smiles><smiles>[O-]C(=NC(=C/I)/C(O)=N/c1ccccc1)c1ccccc1</smiles>

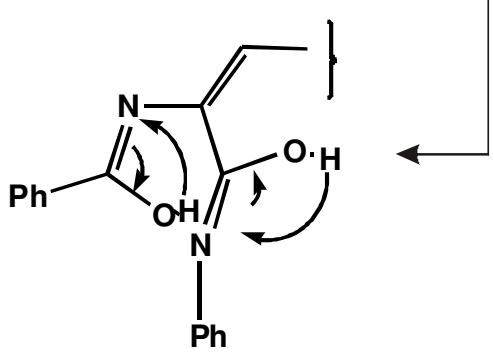

Scheme-II: A possible mechanism showing the formation of 5(4H)-imidazolone

\begin{tabular}{|c|c|c|c|c|c|}
\hline \multicolumn{6}{|c|}{$\begin{array}{c}\text { TABLE } 1 \\
\text { PERCENTAGE YIELDS OF IMIDAZOLONES (17-21) WITH VARIOUS CATALYSTS }\end{array}$} \\
\hline Compound & 17 & 18 & 19 & 20 & 21 \\
\hline \multicolumn{6}{|l|}{ Catalyst } \\
\hline Conventional heating & $22(14.30 h)^{\mathrm{a}}$ & $26(15 \mathrm{~h})^{\mathrm{a}}$ & $20(15 \mathrm{~h})^{\mathrm{a}}$ & $23(13 \mathrm{~h})^{\mathrm{a}}$ & $25(13.30 \mathrm{~h})^{\mathrm{a}}$ \\
\hline $\mathrm{SiO}_{2}$ & $25(14 \mathrm{~h})^{\mathrm{a}}$ & $30(13 \mathrm{~h})^{\mathrm{a}}$ & $28(13 \mathrm{~h})^{\mathrm{a}}$ & $28(13 \mathrm{~h})^{\mathrm{a}}$ & $32(13 \mathrm{~h})^{\mathrm{a}}$ \\
\hline $\mathrm{Al}_{2} \mathrm{O}_{3}-90$ & $45(12 \mathrm{~h})^{\mathrm{a}}$ & $43(11.30 \mathrm{~h})^{\mathrm{a}}$ & $33(13 \mathrm{~h})^{\mathrm{a}}$ & $30(13 h)^{a}$ & $36(11 \mathrm{~h})^{\mathrm{a}}$ \\
\hline Y-H Zeolite & $78(4.30 \mathrm{~h})^{\mathrm{a}}$ & $75(4.30 h)^{a}$ & & $66(6.30 \mathrm{~h})^{\mathrm{a}}$ & $68(5.30 \mathrm{~h})^{\mathrm{a}}$ \\
\hline
\end{tabular}




\begin{tabular}{|c|c|c|c|c|c|c|c|c|c|c|c|c|}
\hline \multicolumn{13}{|c|}{$\begin{array}{c}\text { TABLE } 2 \\
\text { ANTIFUNGAL EVALUATION OF IMIDAZOLONES (17-21) }\end{array}$} \\
\hline \multicolumn{13}{|c|}{ Diameter of zone of inhibition $(\mathrm{mm})$} \\
\hline Conc. $(\mu \mathrm{g} / \mathrm{mL})$ & \multicolumn{4}{|c|}{ Fusarium oxysporum } & \multicolumn{4}{|c|}{ Rhizoctonia solani } & \multicolumn{4}{|c|}{ Curvularia lunata } \\
\hline Compd. & 5 & 25 & 50 & 100 & 5 & 25 & 50 & 100 & 5 & 25 & 50 & 100 \\
\hline 17 & - & 13 & 14 & 15 & 15 & 18 & 19 & 19 & 13 & 14 & 16 & 19 \\
\hline 18 & - & 16 & 19 & 19 & 19 & 20 & 22 & 24 & 9 & 10 & 18 & 20 \\
\hline 19 & - & - & - & 5 & 9 & 11 & 13 & 14 & 7 & 9 & 9 & 10 \\
\hline 20 & 7 & 9 & 10 & 10 & 10 & 11 & 13 & 15 & 9 & 10 & 10 & 11 \\
\hline 21 & - & 6 & 7 & 7 & 6 & 7 & 8 & 8 & 7 & 8 & 8 & 9 \\
\hline Bavistine & - & 17 & - & - & 18 & 20 & 22 & - & - & 15 & 16 & 20 \\
\hline
\end{tabular}

the standard drug. The MIC values were better for compounds 17-20 against $C$. lunata compared to the standard drug. Strong electron withdrawing groups on phenyl ring in compounds $\mathbf{1 8}$ and $20\left(-\mathrm{Cl} \&-\mathrm{NO}_{2}\right)$ could obviously effect on pharmacological activity and antifungal spectrum.

\section{Conclusion}

In conclusion we have developed a new synthetic methodology for a facile synthesis of 5(4H)-imidazolones using Y-H zeolite, $\mathrm{SiO}_{2}$ and $\mathrm{Al}_{2} \mathrm{O}_{3}-90$. These compounds exhibited potent antimicrobial activity against the specified phytopathogens. The conclusions made were just preliminary, further studies on their synthesis and other pharmacological properties are in progress.

\section{ACKNOWLEDGEMENTS}

The authors thank DRDO, New Delhi, India for their financial assistance and also to Department of Microbiology, Andhra University, India for conducting antifungal studies.

\section{REFERENCES}

1. A.C. Cuckler, A.B. Kupferberg and N. Hillman, Antibiot. Chemother., 5, 540 (1955).
2. H.K. Urman, O. Bulay, D.B. Clayson and P. Shubik, Cancer Lett., 1, 69 (1975).

3. W.B. Wright Jr. and H.J. Brabander, J. Org. Chem., 26, 4051 (1961).

4. V. Niedbalia and I. Buctteher, Chem. Abstr., 94, 15732 (1981).

5. K.J. Shaw, P.W. Erhardt, A.A. Hagedom, C.A. Pease, W.R. Ingebretsen and J.R. Wiggins, J. Med. Chem., 35, 1267 (1992).

6. A. Nefzi, J.M. Ostresh and R.A. Houghten, Chem. Rev., 97, 449 (1997).

7. J.W. Cornforth and H.T. Huang, J. Chem. Soc., 731 (1948).

8. H. Lehr, S. Karlan and M.W. Goldberg, J. Am. Chem. Soc., 75, 3640 (1953).

9. L.D.S. Yadav and S. Singh, Synthesis, 63 (2003).

10. Z. Hell, A. Cwik, Z. Finta and Z. Horváth, J. Mol. Catal. A, 184, 191 (2002).

11. R. Roy, Science, 238, 1664 (1987).

12. A.L. McKenna in Kirk-othmer, Encyclopedia of Chemical Technology, Aluminium Carboxylates, Wiley, New York, vol. 2, p. 273 (1991).

13. Y.L.N. Murthy, V. Christopher, U.V. Prasad, P.B. Bisht, D.V. Ramanaih, B.S. Kalanoor and S.A. Ali, Synth. Met., 160, 535 (2010).

14. K. Smith, M. Butters and B. Nay, Synthesis, 1157 (1985).

15. P. Ratnasamy, A.P. Singh and S. Sharma, Appl. Catal. A, 135, 25 (1996).

16. S.A. Siddiqui, S.R. Bhusare and D.V. Jarikote, Bull. Korean Chem. Soc., 22, 1033 (2001).

17. C.P. Pauli and P. Bazerque, Acta Biol. Med. Exper., 15, 113 (1990).

18. P.R. Murray, E.J. Baron and M.A. Pfaller, Manual of clinical Microbiology, ASM Press, Washington D.C., edn 6 (1995). 